\title{
Effect of Poultry Manure and N.P.K 15: 15: 15 Fertilizer on the Growth and Yield of Nsukka Yellow Pepper (Capsicum annum)
}

\author{
Awere, S.U ${ }^{1} ;$ Omeje, T.E ${ }^{2}$ \\ ${ }^{1}$ Department of Agronomy and Ecological Management, Enugu State University of Science and Technology P.M.B 01660 \\ Enugu, Nigeria. \\ ${ }^{2}$ Department of Agricultural Technology, Enugu State Polytechnic Iwollo, Enugu State, Nigeria.
}

\begin{abstract}
A field experiment to evaluate the effect of poultry manure and N.P.K 15:15:15 fertilizer on the growth and yield of Nsukka yellow pepper (Capsicum annum) was conducted in the faculty of Agriculture and Natural Resources Management Teaching and Research Farm Enugu State University of Science and Technology Enugu during the 2018 cropping season. The experiment was carried out using a randomized complete block design ( $R C B D)$ with four (4) treatments replicated five (5) times. The result of the experiments showed significant treatment effect $(P=0.05)$ on the following agronomic parameters measured; percentage $(\%)$ plant survival, leaf area index, plant height, number of leaves per plant, number of days to $50 \%$ flowering, number of fruits per plant and fruit yield $(\mathrm{kg} / \mathrm{ha})$. Poultry manure and N.P.K 15:15:15 fertilizer combination performed significantly $(P=0.05)$ better than poultry manure, N.P.K 15:15:15 fertilizer and no application of the treatments on the number of leaves per plant, number of fruits per plant and fruit yield $(\mathrm{kg} / \mathrm{ha})$. There was neither significant interaction effect $(P=0.05)$ of poultry manure + N.P.K 15:15:15 fertilizer nor significant main effect $(P=0.05)$ of poultry manure and N.P.K 15:15:15 fertilizer on leaf area index.
\end{abstract}

Keywords- Nsukka yellow pepper (Capsicum annum), poultry manure, N.P.K 15:15:15: fertilizer, interaction effect, main effect.

\section{INTRODUCTION}

Capsicum species popularly known as pepper is the world's second most important vegetable crop after tomato (Yoon et. al. 1989). In contrast, (Uzo, 1983) stated that pepper occupies the third position of importance among cultivated vegetable after onions and tomatoes. Bosland (1994) stated that genus Capsicum belongs to the family solanaceae. Uguru and Obieri (2008) stated that Nsukka yellow pepper belongs to the family of solanaceae and the genus Capsicum. This crop is grown for its fruits. It is an indispensable commodity and an integral component of many cuisines in the world due to its appealing flavour, taste and pungency (Bosland and Votava 2000). Five species of pepper were domesticated; Capsicum annum, Capsicum frutescens, Capsicum baccatum, Capsicum Chinese and Capsicum pubscens. Among these species, Capsicum annum is the most widely spread and most important. The plant is a herbaceous annual growing from $45 \mathrm{~cm}-65 \mathrm{~cm}$ tall. One to three (1-3) fruits do occur in the axils of one leaf. It is also characterized by its yellow colour at fruit ripening and a unique aroma which distinguish it from other pepper varieties.

Capsicum species is grown in most countries of the world such as China, Turkey, Mexico, Spain and U.S.A, among which Nigeria is ranked third producer of pepper in the world (Uguru and Obieri 2008). Pepper is an indigenous vegetable of Nigeria and as such, its production is an important component of both subsistence and commercial farming system generally practiced in Nigeria especially Enugu State (Tanko 1995).

Nigeria is one of the most important countries in the world for pepper genetic resources since it accounts for $50 \%$ out of million tones believed to be produced in Africa, following the world estimated area of 1.6 million hectares with China being the largest producer and 1 million tones believed to be produced in Africa (FAOSTAT 2013). Consumption of pepper accounts for about $20 \%$ of the average vegetable consumption per person per day in Nigeria (Alegbejo, 2002). Nsukka yellow pepper is a vegetable fruit consumed either fresh or dehydrated/dried. It is very nutritious and has medicinal value and is a recognized source of vitamin A, $\mathrm{C}$ and E. In addition, it is a source of antioxidant, nutrients, as well as bioactive compound such as flavonoids, phenolic acid, carotenoids and also rich in natural colour and aroma. The key bioactive compounds in peppers such as flavonoids, capsaicinoides and capsicinoids have been linked to biochemical and pharmacological effect including anti-oxidation and antiinflammation activities. Capsaicinoids provide the 
pungent sensation in hot pepper, whereas capsicinoids are non pungent compounds present in sweet peppers.

Capsicinoids have been reported to have antiinflammatory activities as well as to promote energy consumption, suppress fat accumulation and increase body temperature in humans. The activities of capsicinoids and their lack of pungency, make them attractive for potential application in food and pharmacology. Other major bio-active compounds of pepper includes ascorbic acid, carotenoids and other antioxidants. The culinary properties and biological effect of bioactive compounds make them extremely important not only for nutrition, but also as pharmacological substance that are used in prevention of cardiovascular disease, cancers and cataracts. In addition, it is used for preservation of cowpea and other grains against weevils attacks.

Generally, pepper production has not attracted the same research patronage like other crops such as cassava, cowpea, cocoa, and Rice especially in Nigeria (Awoke and Okorji 2004). As a result, a few or no research has been conducted to find out why Nsukka yellow pepper is not grown in many parts of Nigeria especially in areas with low soil fertility. As a result of this, I decided to initiate a research work that aimed at evaluating the effect of poultry manure and N.P.K 15:15:15 fertilizer on the growth and yield of Nsukka yellow pepper (Capsicum annum) in Enugu area of south eastern Nigeria.

\section{MATERIALS AND METHODS}

Field experiment to evaluate the effect of poultry manure and N.P.K 15:15:15 fertilizer on the growth and yield of Nsukka yellow pepper (Capsicum annum) was carried out during the 2018 cropping season at the Faculty of Agriculture and Natural Resources Management Teaching and Research Farm of Enugu State University of Science and Technology Enugu, Southeastern Nigeria. The University lies between latitude $06^{0} 50^{\prime} \mathrm{N}-06^{0} 57^{\prime} \mathrm{N}$ and longitude $07^{0} 15^{\prime} \mathrm{E}-07^{0} 18^{\prime} \mathrm{E}$ with a mean elevation of $450 \mathrm{~m}$ above sea level.

\section{Experiment Design}

The experiment was carried out using a randomized complete block design (RCBD) with four (4) treatments replicated five (5) times. The experimental area measured $14 \mathrm{~m} \times 11 \mathrm{~m}\left(154 \mathrm{~m}^{2}\right)$. Each plot (experimental unit)

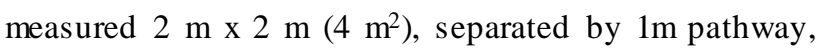
with plant spacing of $50 \mathrm{~cm} \times 50 \mathrm{~cm}$. the pepper seedlings were raised in a nursery before they were transplanted into the field.

\section{Treatments}

Treatments were; (i) No poultry manure and no N.P.K 15:15:15 fertilizer.

(ii) Poultry manure (6.4 tons/ha)

(iii) N.P.K 15:15:15 fertilizer (200 kg/ha) (iv) Poultry manure (3.2 ton/ha) + N.P.K 15:15:15 fertilizer (100 $\mathrm{kg} / \mathrm{ha}$ ).

\section{Data Collection}

Data were collected on percentage (\%) plant survival, plant height $(\mathrm{cm})$, number of leaves per plant, leaf area index, number of days to $50 \%$ flowering, number of fruits per plant and fruit yield $(\mathrm{kg} / \mathrm{ha})$.

\section{Data Analysis}

The data collected were subjected to analys is of variance for randomized complete block design (RCBD) experiment as outlined by Obi 2002 using Genstat Release 10.3DE (PC. windows) 2012 software. Differences between treatment means were detected using fisher's least significant difference $\quad$ (F - LSD) as outlined by Steel and Torrie (1980).

\section{RESULTS}

Effect of poultry manure and N. P.K15:15:15 fertilizer on percentage $(\%)$ plant survival, plant height $(\mathrm{cm})$ and leaf area index.

The result of the experiment showed significant effect ( $P$ $=0.05)$ of poultry manure and N.P.K 15:15:15 fertilizer on percentage $(\%)$ plant survival and plant height $(\mathrm{cm})$, and non-significant effect $(\mathrm{P}=0.05)$ on leaf area index. Poultry manure recorded the highest mean number of 92.50\% survived plants, followed by poultry manure + N.P.K 15:15:15 fertilizer that had mean number of $90.00 \%$ survived plants and lastly, no poultry manure and no N.P.K 15:15:5 fertilizer that had mean number of $67.50 \%$ survived plants. On plant height plots treated with N.P.K 15:15:15 fertilizer recorded the highest mean plant height of $42.70 \mathrm{~cm}$, followed by plots treated with poultry manure + N.P.K 15:15:15 fertilizer that recorded mean plant height of $38.13 \mathrm{~cm}$ and lastly plots treated with no poultry manure and no N.P.K 15:15:15 fertilizer that had mean plant height of $29.83 \mathrm{~cm}$. Although there was nonsignificant effect of the treatments on leaf area index, poultry manure recorded the highest mean leaf area index of 3.66 followed by poultry manure + N.P.K 15:15:15 fertilizer that recorded mean leaf area index of 3.29 and lastly no poultry manure and no N.P.K 15:15:15 fertilizer treatment that had mean leaf area index of 1.73 (Table1). 
Table.1: Effect of poultry manure and N.P.K 15:15:15 fertilizer on plant survival (\%), plant height (cm) and leaf area index.

\begin{tabular}{|c|c|c|c|}
\hline Treatments & Plant survival (\%) & Plant height (cm) & Leaf area index \\
\hline None & 67.50 & 29.83 & 1.73 \\
\hline Poultry manure & 92.50 & 35.50 & 3.66 \\
\hline N.P.K 15:15:15 Fertilizer & 76.30 & 42.70 & 1.73 \\
\hline \multicolumn{4}{|l|}{$\begin{array}{c}\text { Poultry manure } \\
+\end{array}$} \\
\hline N.P.K 15:15:15 fertilizer & 90.00 & 38.13 & 3.29 \\
\hline F-LSD 0.05 & 12.20 & 9.26 & NS \\
\hline
\end{tabular}

Effect of poultry manure and N.P.K 15:15:15 fertilizer on the number of leaves per plant and number of days to $50 \%$ flowering.

Statistical analys is of the experiment showed a significant effect $(\mathrm{P}=0.05)$ of poultry manure and N. P.K15:15 15 fertilizer on the number of leaves per plant and also number of days to $50 \%$ flowering.

Plots treated with poultry manure + N.P.K 15:15:15 fertilizer recorded the highest number of 296.0 leaves per plant followed by plots treated with poultry manure that recorded 183.4 leaves per plant and lastly plots treated with no poultry manure and no N.P.K 15:15:15 fertilizer that had a record of 38.00 leaves per plant.

The result also showed that plots treated with no poultry manure and no fertilizer recorded the highest number of 76. 50 days to $50 \%$ flowering, followed by plots treated with N.P.K 15:15:15 fertilizers that had a record of 61.60 days to $50 \%$ flowering and lastly plots treated with poultry manure that recorded 35.00 days to $50 \%$ flowering (Table 2).

Table.2: Effect of poultry manure and N.P.K 15:15:15 fertilizer on the number of leaves per plant and number of days to $50 \%$ flowering.

Treatments Number of leaves per plant Number of days to

$50 \%$ flowering

None

38.00

Poultry manure

183.40

84.20

76.50

Poultry manure

$+$

N.P.K 15:15:15 fertilizer

296.00

35.20

F-LSD 0.05

85.40

13.12

Effect of poultry manure and N.P.K 15:15:15 fertilizer on the number of fruits per plant and fruit yield (kg/ha).
The result of the experiment showed significant effect $(\mathrm{P}=0.05)$ of poultry manure and N.P.K 15.15.15 fertilizer on the number of fruits per plant and fruit yield 
(kg/ha) of Nsukka yellow pepper (Capsicum annum).

Poultry manure + N.P.K. 15:15:15 fertilizer recorded the highest number of 26.0 fruits per plant followed by poultry manure that recorded 4.0 fruits per plant. Again poultry manure + N.P.K 15:15:15: fertilizer had the highest fruit yield of $4768.75 \mathrm{~kg} / \mathrm{ha}$, followed by poultry manure that recorded fruit yield of $2106.25 \mathrm{~kg} / \mathrm{ha}$ and lastly, no poultry manure and no N.P.K 15:15:15 fertilizer that had fruit yield of $81.25 \mathrm{~kg} / \mathrm{ha}$ (Table 3).

Table.3: Effect of poultry manure and N. P.K15:15 15 fertilizer on the number of fruits per plant and fruit yiel ded ( $\mathrm{kg} / \mathrm{ha})$.

\section{Treatments}

\section{Number of fruits per plant}

\section{Fruit yield (kg/ha)}

\begin{tabular}{|c|c|c|}
\hline None & 4.0 & 81.25 \\
\hline Poultry manure & 14.0 & 2106.25 \\
\hline N.P.K $15: 15: 15$ fertilizer & 11.0 & 581.25 \\
\hline \multicolumn{3}{|l|}{$\begin{array}{c}\text { Poultry manure } \\
+\end{array}$} \\
\hline N.P.K. $15: 15: 15$ fertilizer & 26.0 & 4768.75 \\
\hline F-LSD 0.05 & 9.8 & 79.25 \\
\hline
\end{tabular}

\section{DISCUSSION AND RECOMMENDATION}

The result of the experiment showed that plots treated with poultry manure recorded the highest plant survival which was not significantly different from that of poultry manure + N.P.K 15:15:15 fertilizer (Table 1). Again, on fruit yield $(\mathrm{kg} / \mathrm{ha})$, plots treated with poultry manure + N.P.K 15:15:15 fertilizer recorded the highest fruit yield of $4768.75 \mathrm{~kg} / \mathrm{ha}$ which was significantly different from that of poultry manure that recorded fruit yield of $2106.25 \mathrm{~kg} / \mathrm{ha}$ (Table 3). Since plots treated with poultry manure + N.P.K 15:15:15 fertilizer produced fruit yield that was significantly higher than that of poultry manure, and also produced percentage plant survival that was not significantly different from that of the poultry manure, Nsukka yellow pepper producer/farmers in Enugu area should combine poultry manure and N.P.K 15:15:15 fertilizer in order to maximize yield and also reduce crop loss in the farm.

On plant height, plots treated with N.P.K 15:15:15 fertilizer recorded the highest plant height of $42.70 \mathrm{~cm}$, followed by plots treated with poultry manure + N.P.K 15:15:15 fertilizer that recorded plant height of $38.13 \mathrm{~cm}$ which was not significantly different from that of N.P.K 15:15:15 fertilizer. Therefore, Nsukka yellow pepper farmers within Enugu area, whose aim is to produce crop of high yielding and optimum plant height for easy harvest should apply a combination of poultry manure and N.P.K 15:15:15 fertilizer since the combination recorded a significant higher yield as earlier indicated (Table 3).

In areas where erosion of top soils by rain drops is a problem, Nsukka yellow pepper producers/farmers should apply a combination of poultry manure and N.P.K 15:15:15 fertilizer as this treatment recorded the highest leaf area index of 3.66 and also the highest fruit yield since leaf area index indicates the extent of land area coverage by plant leaves.

\section{REFERENCES}

[1] Alegbejo, M.D. (2002). Evaluation of pepper cultivar for resistance to pepper veinal mottle poliovirus in Northern Nigeria. Journal of Arid Agriculture 12:93 - 103.

[2] Awoke, C.P. and Okorji (2004). The determination and analysis of constraints in resources use efficiency in multiple cropping system by small holder farmers in Ebonyi State Nigeria. Council for the Development of Social Science research in Africa, vol. xxix, No 358 - 61pp.

[3] Bosland, P.W. (1994). History and uses of spices, herbs and edible fungi. Elsevier publication, New York 3336pp.

[4] Bosland, P.W. (2000). Article on pepper (Capsicum annum) as vegetables and spices. A publication of CABI publishing walling 1:204. 
[5] FAOSTAT, (2013). Food and Agricultural organization of the United Nations statistical data base. Retrieved from www.fao.org.

[6] Obi, I.U. (2002). A book on Statistical Methods of detecting differences between treatment means. SNAAP Nigeria Ltd. Enugu.

[7] Steel, R.G.D and Torrie, J.H. (1980). Principles and procedure of statistics a Biometrical Approach, Second edition, Mc Grass Hill Inc. New York pp 633.

[8] Tanko, N. (1995). Contribution of rural women to Agricultural planning development in Nigeria: In Sustainable Agriculture and economic development in Nigeria, edited by Ikpi, J.E and Olayemi J. Published by Arkansans Winrock International.

[9] Uguru, M.I and Obieri (2008). Household sustenance potentials of women through blanching and salting techniques of processing and preservation of Nsukka yellow pepper (Capsicum annum). Unpublished Ph.D Thesis in the Crop Science Department, Faculty of Agriculture University of Nigeria Nsukka.

[10] Uzo, J.O. (1983). Vegetable crop production in the tropics; a case study of Nigeria in West Africa. Longman publishers England page 18. 